\title{
Ocena konkurencyjności spółdzielni mleczarskich
}

\section{Wstęp}

Branża mleczarska zajmuje znaczącą pozycję w przemyśle spożywczym w Polsce. W 2001 r. wartość produkcji sprzedanej polskich przedsiębiorstw mleczarskich wynosiła $16 \%$ ogółu produkcji sprzedanej polskiego przemysłu spożywczego. W przemyśle mleczarskim zatrudnionych było około 53 tys. osób, co stanowiło $16 \%$ ogółu zatrudnionych w przemyśle spożywczym [Chechelski, Morkis 2002]. W Skorygowanym Programie Restrukturyzacji Mleczarstwa w Polsce (SPRM) ${ }^{1}$, mającym spełniać rolę koordynatora dla tworzenia modelu i realizacji nowoczesnej gospodarki mleczarskiej, przewidziano miejsce dla wszystkich podmiotów spółdzielczych, prywatnych i z udziałem kapitału zagranicznego. Jednak ciężar przekształceń $\mathrm{w}$ najszerszym zakresie dotyczy spółdzielczości mleczarskiej. Ustalenie listy zakładów mleczarskich w poszczególnych ich kategoriach stało się ważnym etapem na drodze dostosowywania polskiego mleczarstwa do wymogów i standardów UE. Przedsiębiorstwa mleczarskie w ramach przeprowadzonej klasyfikacji zostały zaliczone do 4 następujących kategorii:

- kategoria A - zakłady spełniające wymagania UE,

- kategoria B1 -zakłady, które do momentu akcesji mają spełnić wymagania $\mathrm{UE}$,

\footnotetext{
${ }^{1}$ Skorygowany Program Restrukturyzacji Mleczarstwa (SPRM) w Polsce został zaakceptowany w styczniu 1999 r. przez Ministra Rolnictwa i Gospodarki Żywnościowej (MRiGŻ - obecnie MRiRW). Jego myślą przewodnią i głównym zamiarem było opracowanie metod i sposobów rozwiązań, które w moźliwie najkrótszym czasie pozwolą na zniwelowanie dysproporcji między mleczarstwem Polski i UE w trzech dziedzinach: produkcji mleka, przetwórstwie oraz dystrybucji i marketingu. Program ten był kontynuacją rządowego programu opracowanego przez Krajowy Związek Spółdzielni Mleczarskich (KZSM) i zaakceptowanego przez MRiGŻ 1 sierpnia $1994 \mathrm{r}$.
} 
- kategoria B2 - zakłady, które, aby spełnić wymagania UE, będą ubiegały się o ściśle określony okres przejściowy, w którym muszą zrealizować wiele konkretnych zadań dostosowujących wszystkie linie produkcyjne i strukturę produkcji do standardów UE,

- kategoria C - zakłady, które $\mathrm{z}$ uwagi na dotychczasowe zaniedbania w zakresie jakości i standardów nie są w stanie zrealizować działań dostosowawczych; w związku z tym będą mogły prowadzić działalność produkcyjną tylko do momentu akcesji i ulegną likwidacji.

Celem badań była analiza porównawcza spółdzielni mleczarskich w zakresie kształtowania się poziomu ich konkurencyjności. Analizą objęto dwie grupy spółdzielni mleczarskich. Pierwszą są spółdzielnie uprawnione do eksportu na rynki krajów UE, drugą zaś grupę stanowia spółdzielnie mleczarskie funkcjonujące $\mathrm{w}$ województwie świętokrzyskim, takich uprawnień nie posiadające. $\mathrm{Na}$ podstawie listy polskich zakładów mleczarskich uprawnionych do eksportu na rynki państw członkowskich UE (kategoria A), według stanu na 31.12.2001 r. liczącej 25 zakładów, wyodrębniono 12 zakładów działających w formie spółdzielni. Zgodę na przeprowadzenie badań uzyskano z 8 spółdzielni mleczarskich (woj.: podlaskie - 3 spółdzielnie, łódzkie - 2, mazowieckie - 1, wielkopolskie - 1, kujawsko-pomorskie - 1). W dalszej części badań grupa tych spółdzielni będzie określana jako „grupa A". Druga grupa spółdzielni (określana w badaniach jako „grupa B”) to spółdzielnie mleczarskie zlokalizowane w województwie świętokrzyskim. W tym przypadku spółdzielcza forma własności stanowi prawie całą populację zakładów przetwórstwa mleka, gdyż na 12 zakładów 11 stanowią spółdzielnie. Zgodę z tej grupy na wzięcie udziału w badaniach zadeklarowało także 8 spółdzielni mleczarskich. Ostatecznie badaniem objęto 16 spółdzielni mleczarskich, po $8 \mathrm{z}$ każdej grupy. Badania przeprowadzono w 2001 r. z wykorzystaniem kwestionariusza wywiadu z prezesami spółdzielni mleczarskich.

Należy podkreślić duże zróżnicowanie regionalne potencjału polskiego mleczarstwa. Część mleczarni reprezentuje światowy poziom przetwórstwa. Większość jednak jednostek spółdzielczych przetwórstwa mleczarskiego osiaga małą rentowność i ma niedostateczną płynność finansowa, co zmniejsza ich zdolności samodzielnego inwestowania [Wasilewski, Kowalczyk 2003a]. W województwie świętokrzyskim nie ma spółdzielni mleczarskich zakwalifikowanych do kategorii A. Konieczność zatem dostosowania mleczarstwa tego województwa do wymagań UE, wskazuje na pilną potrzebę adaptacji spółdzielni mleczarskich do funkcjonowania na zintegrowanym rynku. Jednocześnie uwarunkowania przyrodnicze i gospodarcze oraz demograficzne regionu Gór Świętokrzyskich stwarzają podstawy do przypisania temu województwu cech określających województwo rolniczym i mającym w skali kraju dość ko- 
rzystne warunki dla jego rozwoju. Ponadto, produkcja mleka dla dużej grupy gospodarstw, ze względu na bardzo ograniczone możliwości uzyskania dochodu spoza gospodarstwa (stopa bezrobocia powyżej średniej w kraju), stanowi podstawę utrzymania rodzin rolniczych, gdyż comiesięczna zapłata za mleko jest źródłem środków na zakup niezbędnych artykułów żywnościowych i środków do produkcji.

\section{Wyniki badań}

Analizowane grupy spółdzielni charakteryzowały się znacznym zróżnicowaniem pod względem rozmiarów prowadzonej działalności. Spółdzielnie z grupy A, mające możliwość eksportu na rynek UE, są zakładami dużymi. Każda ze spółdzielni tej grupy przerabia powyżej $40 \mathrm{mln} 1 \mathrm{mleka} w$ roku, zatem zgodnie z kryteriami przyjętymi w SPRM jest zaliczana do spółdzielni dużych ${ }^{2}$. Sredni przerób surowca przez spółdzielnie w tej grupie wahał się od około $130 \mathrm{mln}$ $1 \mathrm{w} 1998$ r. do ponad $162 \mathrm{mln} 1 \mathrm{w} 2001 \mathrm{r}$. (tab. 1). W tej grupie znajdują się największe spółdzielnie mleczarskie w kraju. Przerób mleka w największej spółdzielni w grupie A w 1998 r. wyniósł $250 \mathrm{mln}$ 1, a w 2001 r. wzrósł do $414 \mathrm{mln}$ 1, co daje średni przerób powyżej $1 \mathrm{mln}$ litrów mleka na dobę. Najmniejsza spółdzielnia w tej grupie charakteryzowała się przerobem w granicach $56 \mathrm{mln} 1$ w 1998 r. i 60 mln 1 w ostatnim roku objętym analiza. Spółdzielnie grupy A zanotowały w latach 1998-2001 wzrost ilości przerabianego mleka średnio o $25 \%$, przy czym niektóre z nich zanotowały wzrost przerobu od $30 \%$ do nawet $66 \%$. Tak duże zmiany ilości przerabianego mleka były wynikiem dokonywanych procesów łączenia się spółdzielni. Właśnie w tej grupie spółdzielni znajdują się takie, które były pionierami procesów konsolidacyjnych w sektorze przetwórstwa mleka w Polsce. W związku z tymi działaniami następował tak duży wzrost ilości przerabianego mleka, który dokonywał się w sposób skokowy.

W grupie spółdzielni B dominują zakłady małe, przerabiające poniżej 20 mln 1 mleka rocznie. Jedynie dwie spółdzielnie przerabiają większe ilości surowca, jednak znajdują się one na granicy przedziałów, tzn. jedna $\mathrm{z}$ nich przerabia nieco ponad $20 \mathrm{mln} 1$ mleka rocznie, jest więc spółdzielnią średniej wielkości. Największa spółdzielnia w tej grupie w latach 1998, 2000 i 2001 przekraczała nieznacznie poziom przerobu w wysokości $50 \mathrm{mln} 1$, a więc mogła być zaliczona do spółdzielni dużych. W 2001 roku w grupie spółdzielni B nastapił

\footnotetext{
${ }^{2}$ Zgodnie ze SPRM zakłady mleczarskie dzielą się na 3 grupy: małe - przerabiające do $20 \mathrm{mln} 1$ mleka rocznie, średnie - przerabiające $20-40 \mathrm{mln} 1 \mathrm{mleka}$ rocznie, duże - przerabiające powyżej $40 \mathrm{mln} 1 \mathrm{mleka}$ rocznie.
} 
spadek ilości przetwarzanego mleka do poziomu 84,5\% z $1998 \mathrm{r}$. Jedną z przyczyn tego zjawiska jest spadek pogłowia bydła mlecznego w województwie świętokrzyskim. Jest to zatem sytuacja odwrotna w porównaniu do województwa podlaskiego, w którym nastapił $\mathrm{w}$ badanym okresie wzrost liczby krów. Województwo to jest uważane obecnie za zagłębie mleczne i stanowi wysokiej jakości bazę surowcową dla spółdzielni mleczarskich. Wzrostowe tendencje przerobu mleka $\mathrm{w}$ spółdzielniach grupy A są pochodną rozwoju spółdzielczości mleczarskiej w województwie podlaskim, gdyż dwie spółdzielnie o największym wolumenie przerobu funkcjonują właśnie w tym regionie. Ponadto w 1998 r. najmniejsza spółdzielnia grupy A przerabiała prawie taką samą ilość mleka, jak największa ze spółdzielni w grupie B. W 2001 r. spółdzielnia $\mathrm{z}$ grupy $\mathrm{B}$ o największym rocznym przerobie surowca przerobiła mniej niż najmniejsza ze spółdzielni zaliczonych do grupy A. Zestawienie to wskazuje na różnice $\mathrm{w}$ skali działalności prowadzonej przez badane grupy spółdzielni.

\section{Tabela 1}

Przerób i jakość surowca w spółdzielniach

\begin{tabular}{|l|c|c|c|c|c|c|c|c|}
\hline & \multicolumn{5}{|c|}{ Grupa A } & \multicolumn{4}{c|}{ Grupa B } \\
\cline { 2 - 9 } & 1998 & 1999 & 2000 & 2001 & 1998 & 1999 & 2000 & 2001 \\
\hline $\begin{array}{l}\text { Udział mleka } \\
\text { klasy extra } \\
\text { w skupie (\%) }\end{array}$ & 46,1 & 55,6 & 69,7 & 76,2 & 6,3 & 10,8 & 20,2 & 24,7 \\
\hline $\begin{array}{l}\text { Przerób su- } \\
\text { rowca } \\
\text { (tys. l/rok) }\end{array}$ & 129689,1 & 126876,8 & 134480,5 & 162098,5 & 16867,5 & 14761,5 & 13799,8 & 14245,0 \\
\hline $\begin{array}{l}\text { Dynamika } \\
\text { przerobu } \\
\left(\begin{array}{l}1998= \\
=100 \%)\end{array}\right.\end{array}$ & 100,0 & 97,8 & 103,7 & 125,0 & 100,0 & 87,5 & 81,8 & 84,5 \\
\hline
\end{tabular}

Źródło: Badania własne.

Spółdzielnie grupy A charakteryzują się znacznie większym udziałem mleka klasy extra w ogólnej ilości skupowanego surowca niż spółdzielnie grupy B. Średni udział mleka klasy extra skupowanego przez te spółdzielnie wzrósł bowiem z 46,1\% w 1998 r. do 76,2\% w 2001 r., tj. o 30,1 pkt. proc. (tab. 1). Bardzo duży postęp w poprawie jakości surowca mlecznego dokonał się również w spółdzielniach grupy $\mathrm{B}$; gdyż średni udział mleka klasy extra wzrósł z poziomu 6,3\% w 1998 r. do 24,7\% w 2001 r., a więc około czterokrotnie. Jednak nadal udział najlepszego jakościowo mleka w skupie realizowanym przez spółdzielnie grupy B jest ponadtrzykrotnie niższy niż w grupie A i jedno- 
cześnie ponaddwukrotnie niższy od średniego udziału mleka extra w skali całego kraju, który na koniec 2001 r. wynosił 58\% [Analizy Rynkowe 2002].

Średnia liczba dostawców surowca do spółdzielni w grupie A wyniosła 5926 w 1998 r. i 5788 dostawców w 2001 r. (tab. 2). W analizowanym okresie w tej grupie spółdzielni średnia liczba dostawców utrzymywała się praktycznie na niezmienionym poziomie, ale zróżnicowanie liczby dostawców surowca w poszczególnych spółdzielniach stanowiących grupę A było duże: od 2087 do $13000 \mathrm{w} 1998$ r. i od 1650 do 13000 w 2001 r. W grupie B spółdzielni mleczarskich średnia liczba dostawców mleka do spółdzielni zmniejszyła się z 3118 w 1998 r. do 2283 dostawców w 2001 r. W tym okresie tempo spadku średniej liczby dostawców przypadających na spółdzielnię z grupy B było ponaddziesięciokrotnie szybsze od tempa spadku zanotowanego $w$ grupie A. Średnia liczba dostawców mleka w latach 1998-2001 w grupie spółdzielni świętokrzyskich spadła o 26,8\%, podczas gdy w grupie A o 2,3\%.

Tabela 2

Liczba dostawców i wielkość dostaw do spółdzielni

\begin{tabular}{|l|c|c|c|c|c|c|}
\hline Wyszczególnienie & Grupa & 1998 & 1999 & 2000 & 2001 & $\begin{array}{c}\text { Dynamika } \\
2001 / 1998(\%)\end{array}$ \\
\hline $\begin{array}{l}\text { Średnia liczba } \\
\text { dostawców }\end{array}$ & $\mathrm{A}$ & 5926 & 6004 & 5873 & 5788 & 97,7 \\
\cline { 2 - 7 } & $\mathrm{B}$ & 3118 & 2806 & 2482 & 2283 & 73,2 \\
\hline $\begin{array}{l}\text { Średnia wielkość } \\
\text { dostaw (tys. I/rok) }\end{array}$ & $\mathrm{A}$ & 17,93 & 18,22 & 20,29 & 24,18 & 134,9 \\
\cline { 2 - 7 } & $\mathrm{B}$ & 5,69 & 5,70 & 6,24 & 7,10 & 124,8 \\
\hline
\end{tabular}

Źródło: Badania własne.

Średnia wielkość dostaw mleka do spółdzielni realizowana przez rolników była także bardzo zróżnicowana i wypadała zdecydowanie na niekorzyść spółdzielni świętokrzyskich. Jest to bezpośrednim wynikiem istniejącej w tym województwie rozdrobnionej struktury agrarnej i związanej z tym średniej wielkości stada krów mlecznych. Oprócz niekorzystnego wpływu tej sytuacji na możliwość inwestowania gospodarstw w poprawę jakości produkowanego przez nie mleka (przy niewielkiej produkcji mleka nie ma ekonomicznych podstaw do zakupu dojarki czy też zbiornika schładzającego), niska średnia wielkość dostaw surowca do spółdzielni zdecydowanie zwiększa koszty skupu. Na etapie pozyskiwania surowca do produkcji osłabia to w wydatny sposób konkurencyjność spółdzielni województwa świętokrzyskiego (wyższe koszty transportu, badań mleka, utrzymywania służb surowcowych itp.). Średnia wielkość dostaw do spółdzielni grupy A wyniosła odpowiednio 17,9 tys. 1 w 1998 r. i 24,2 tys 1 w 2001 r. W drugiej analizowanej grupie spółdzielni średnia wielkość dostaw zwiększyła się z 5,7 tys. 1 w 1998 r. do 7,1 tys. 1 w 2001 r. W grupie tej nastąpił 
więc wzrost średniej wielkości dostaw od jednego dostawcy o około $25 \%$, jednak wzrost ten był jednocześnie o ponad 10 pkt. proc. niższy od przyrostu zanotowanego $\mathrm{w}$ grupie spółdzielni uprawnionych do eksportu na rynek UE. Różnice w średniej wielkości dostaw mleka zatem jeszcze się pogłębiły.

W grupie A spółdzielnia, która zanotowała największe dostawy surowca skupiła ponad 67 tys. 1 mleka od jednego dostawcy, podczas gdy w grupie spółdzielni świętokrzyskich żadna nie przekroczyła średniego poziomu dostaw powyżej 10 tys. 1 rocznie od jednego dostawcy. Świadczy to o różnych warunkach funkcjonowania badanych grup spółdzielni. Baza surowcowa spółdzielni świętokrzyskich w badanym czteroleciu uległa co prawda pozytywnym zmianom (np. wzrost średnich dostaw), jednak tempo zmian było niższe od czołówki spółdzielni mleczarskich w kraju, a różnice w tym aspekcie jeszcze się pogłębiły. Miało to swoje konsekwencje w osiąganych przez spółdzielnie przychodach i zyskach (tab. 3).

\section{Tabela 3}

Przychody i zyski w spóldzielniach

\begin{tabular}{|c|c|c|c|c|c|c|}
\hline Wyszczególnienie & Grupa & 1998 & 1999 & 2000 & 2001 & $\begin{array}{c}\text { Dynamika } \\
2001 / 1998 \\
(\%)\end{array}$ \\
\hline Przychody (tys. zł) & $\mathrm{A}$ & 136409 & 156206 & 216389 & 253838 & 186,1 \\
\cline { 2 - 7 } & $\mathrm{B}$ & 20957 & 20155 & 22481 & 24079 & 114,9 \\
\hline Zysk netto (tys. zł) & $\mathrm{A}$ & 64,5 & 1058,1 & 2485,7 & 3182,1 & 4933,5 \\
\cline { 2 - 7 } & $\mathrm{B}$ & 109,4 & 181,6 & 12,4 & $-85,1$ & $-77,8$ \\
\hline
\end{tabular}

Źródło: Badania własne.

Badane grupy spółdzielni mleczarskich były zróżnicowane pod względem średniego poziomu przychodów ze sprzedaży. Przeciętne przychody ze sprzedaży w grupie spółdzielni A zwiększyły się ze 136409 tys. zł w 1998 r. do 253 838 tys. zł w 2001 r., tj. o 86,1\%, natomiast w grupie spółdzielni B wzrosły do 24079 tys. zł w 2001 r. (o 14,9\%). Przeciętne przychody uzyskane w grupie spółdzielni świętokrzyskich były zatem o 6,5 do 10,5 razy mniejsze niż w grupie spółdzielni A. Spółdzielnie świętokrzyskie zanotowały w latach 1998-2001 wzrost średnich przychodów ze sprzedaży, jednak tempo przyrostu było ponad 6 razy niższe niż w spółdzielniach grupy A. Nastapił zatem dalszy wzrost dysproporcji pomiędzy badanymi grupami spółdzielni. Ponadto, $\mathrm{w}$ okresie objętym analizą $\mathrm{w}$ grupie spółdzielni świętokrzyskich 5 spośród 8 spółdzielni zanotowało spadek wartości sprzedaży, natomiast w drugiej grupie wszystkie spółdzielnie zwiększyły wartość przychodów ze sprzedaży. 
Dokonując analizy średniego poziomu zysku netto wypracowanego przez spółdzielnie grupy B zauważa się wyższy jego poziom od średniego zysku netto osiągniętego przez spółdzielnie $\mathrm{z}$ grupy A. Jednak po wyeliminowaniu zysku osiagniętego przez jedną ze spółdzielni na drodze zawarcia układu z wierzycielami średnia wartość zysku w 1998 r. dla spółdzielni grupy B wyniosłaby 83,2 tys. zł. Podobnie w 1999 r. osiagnięty średni zysk jest zawyżony w wyniku podobnej operacji w kolejnej spółdzielni. Po wyeliminowaniu tego uwiarygodniony średni zysk netto osiagnięty w 1999 r. wyniósłby około 5 tys. zł. W analizowanym okresie stwierdzono $w$ tej grupie spółdzielni spadek wyniku finansowego, co jest bardzo niepokojące, gdyż spółdzielnie nie mają środków na inwestycje. Brak natomiast inwestycji, w sytuacji konieczności dostosowywania produkcji do wymagań sanitarnych, ogranicza możliwość efektywnego konkurowania ich na rynku. Jedną z przyczyn osiagania niekorzystnych wyników finansowych jest asortyment produkcji oferowany przez większość spółdzielni świętokrzyskich, ograniczony do prostych przetworów mleczarskich (mleko spożywcze, śmietany, twarogi itp.), charakteryzujących się niewielka opłacalnością ich produkcji. Poza tym niewielka skala produkcji w tych spółdzielniach i krótkie serie produkcyjne nie pozwalają na wykorzystanie efektu skali i przez to generowanie zysków. Spółdzielnie z grupy B zanotowały spadek zysku w 2001 r. w stosunku do 1998 r. o 194,5 tys. zk, tj. o 177,8\%, do czego przyczyniła się poniesiona strata w kwocie 85 tys. zl, która wydatnie pogarsza sytuację finansową tych spółdzielni. Spółdzielnie $\mathrm{z}$ grupy A na tym odcinku swej działalności dokonały natomiast dużego postępu, zwiększając blisko 50-krotnie średni poziom zysku netto w badanym okresie i zapewniając sobie tym samym środki potrzebne do sfinansowania niezbędnych inwestycji.

Niezbędnym warunkiem funkcjonowania przedsiębiorstwa $w$ gospodarce rynkowej jest posiadanie przez nie pewnego poziomu konkurencyjności [Skawińska 1999]. Konkurencyjność podmiotów gospodarczych jako kategoria ekonomiczna jest różnie definiowana w literaturze przedmiotu. Istnienie konkurencji zmusza przedsiębiorstwa do zwiększania swojego udziału i umacniania pozycji na rynku, a także do wchodzenia na rynki nowe, bardziej atrakcyjne. Identyfikacja warunków konkurencyjnych w obrębie sektora umożliwia ocenę jego atrakcyjności z punktu widzenia aktualnych i przyszłych inwestorów. Stwarza to konieczność szczegółowego określenia słabości oraz możliwości konkurencyjnych tych przedsiębiorstw. Konkurencyjność jest kategorią wielopłaszczyznowa, postrzeganą $w$ relacji przedsiębiorstwa do rynku i występujących na nim szans strategicznych. Dominuje szerokie rozumienie konkurencyjności jako procesu zmiennego i dynamicznego, w którym występują elementy wynikowe i czynnikowe, a sama analiza konkurencyjności podmiotów jest 
wieloaspektowa, wymagająca również oceny jakościowej istotnych cech działalności gospodarczej danej jednostki [Skawińska 2000].

W analizie atrakcyjności sektora mleczarskiego zastosowano model M.E. Portera [Porter 1992]. Model ten zakłada, że istotą strategii konkurencji jest odniesienie przedsiębiorstwa do jego otoczenia sektorowego. Sytuacja w tym otoczeniu jest kształtowana przez pięć czynników (pięć sił konkurencji), którymi są: siła przetargowa dostawców, siła przetargowa nabywców, natężenie walki konkurencyjnej wewnątrz sektora, bariery wejścia nowych firm i groźba ze strony substytutów. Łączne oddziaływanie pięciu sił wyznacza natężenie konkurencji w danym sektorze, które znajduje odzwierciedlenie w przeciętnej rentowności $w$ danej branży. Celem strategii konkurencji jednostki gospodarczej w danym sektorze jest wyszukanie takiej pozycji, w której przedsiębiorstwo najlepiej może się bronić przed tymi siłami albo spożytkować je na własną korzyść. Znajomość sił leżących u podłoża nacisków konkurencyjnych rzuca światło na silne i słabe strony przedsiębiorstwa, wskazuje, w jakich dziedzinach zmiany strategii mogą przynieść największe korzyści i zwraca uwagę na obszary, w których występujące trendy przypuszczalnie będą miały największe znaczenie jako szanse lub zagrożenia. Ze względu na duże zróżnicowanie badanych grup spółdzielni mleczarskich pod względem potencjału wytwórczego można przypuszczać, że znaczenie działania poszczególnych sił napędowych konkurencji w obydwu grupach może być różne.

W sektorze mleczarskim możemy wyróżnić dostawców: surowca (mleka), komponentów i dodatków (owoców, stabilizatorów, kultur bakteryjnych, podpuszczek, aromatów itp.), energii, innych środków, urządzeń i technologii oraz usług. Biorąc pod uwagę duży udział wartości mleka w kosztach całkowitych, który szacuje się na 50-70\% [Jurczak 1997], analizę siły przetargowej dostawców ograniczono do najważniejszej ich grupy - dostawców mleka. Związki między spółdzielniami mleczarskimi a dostawcami podstawowego surowca do produkcji są bardzo istotne. Rozpatrując tę zależność należy zwrócić uwagę na stan zaplecza surowcowego. W województwie świętokrzyskim istnieje duże rozdrobnienie gospodarstw rolnych. Przeciętna ilość mleka kupionego od jednego dostawcy w $2001 \mathrm{r}$. była blisko 3,5-krotnie niższa niż w grupie A spółdzielni mleczarskich, a udział dostawców sprzedających do spółdzielni w ciagu roku niewielkie ilości surowca (poniżej 18 tys. litrów mleka) wynosił $92 \%$ [Wasilewski, Kowalczyk 2003b]. Duże rozdrobnienie gospodarstw rolnych województwa świętokrzyskiego ogranicza możliwości koncentracji i specjalizacji w zakresie chowu bydła mlecznego, co negatywnie wpływa na tempo uzyskiwania postępu w poprawie jakości podstawowego surowca do produkcji.

Grupa spółdzielni świętokrzyskich siłę przețargową dostawców ocenia wyżej aniżeli grupa A spółdzielni. Najsilniejszego zagrożenia ze strony dostaw- 
ców obydwie grupy spółdzielni mleczarskich upatrują w ich wpływie na jakość uzyskiwanego mleka, przy czym zagrożenie to było wyższe w grupie spółdzielni A (ocena 4,5, tab. 4). W grupie spółdzielni świętokrzyskich stosunkowo silne zagrożenie ze strony dostawców dotyczy możliwości zmiany przez nich spółdzielni odbierającej mleko. Zagrożenie to zwiększa również fakt zmniejszania się liczby dostawców surowca do spółdzielni świętokrzyskich w badanym okresie, czego odzwierciedleniem jest ocena na poziomie 4,0 , podczas gdy w grupie A jedynie 1,9. W warunkach rolnictwa świętokrzyskiego drobni producenci dysponują bowiem alternatywą wobec przemysłu mleczarskiego, którą stanowi sprzedaż sąsiedzka i targowiskowa. Ponadto, brak możliwości finansowych nie pozwala spółdzielniom na zaoferowanie dostawcom mleka korzystniejszych ofert. Prawdopodobieństwo zmiany odbiorcy przez dostawców mleka do spółdzielni grupy A może być mniej atrakcyjne, gdyż dostawcy ci posiadaja większe zaangażowanie kapitałowe w swoich spółdzielniach niż dostawcy mleka do spółdzielni świętokrzyskich. Poza tym uzyskują oni wyższe ceny w skupie za dostarczany surowiec niż w pozostałych spółdzielniach. Dostawcy mleka do spółdzielni świętokrzyskich ze względu na niższe ceny jego skupu częściej poszukują możliwości uzyskania lepszej ceny u innego odbiorcy. W związku z powyższym spółdzielnie świętokrzyskie są bardziej zagrożone w tym zakresie $z$ ich strony. W przypadku utraty części dostawców istnieje bowiem konieczność poszukiwania nowych dostawców, bardziej oddalonych od spółdzielni. Powoduje to m.in. wydłużenie trasy przewozu odbieranego surowca, co spowoduje wzrost kosztów transportu i może prowadzić do obniżenia jego jakości. Wyrazem tych zależności jest również duży wpływ zmiany dostawcy na koszty w grupie spółdzielni B (ocena 4,4), podczas gdy w grupie A był on dużo niższy (ocena 1,6). Spółdzielnie grupy A mogą natomiast zaoferować najlepsze warunki finansowe i zapewnić sprawną organizację odbioru mleka od dostawców. Dostawcy ci posiadają zbyt duże korzyści wynikające ze współpracy z tymi spółdzielniami, aby zmienić odbiorcę. Wpływ dostawców na kierunki działań spółdzielni oraz wpływ głównych dostawców na ilość skupionego mleka jest oceniany wyżej w grupie spółdzielni A (ocena odpowiednio 2,7 oraz 4,0 ). Jest to związane $z$ różnicami w koncentracji produkcji w bazach surowcowych obydwu grup spółdzielni. Więksi producenci dysponują lepszymi warunkami przetargowymi, gdyż mniejsze rozproszenie i większa skala produkcji pozwala im oferować większe partie surowca wysokiej jakości. Ponadto specjalizacja gospodarstw w produkcji mleka i brak innej działalności w gospodarstwie powoduje, że zainteresowanie losami spółdzielni jest duże. Dostawcy tacy są zatem w większym stopniu zainteresowani wpływaniem na kierunki działań swych spółdzielni. 


\section{Tabela 4}

Ocena siły przetargowej dostawców (skala ocen 1-5)

\begin{tabular}{|l|l|c|c|}
\hline Lp. & \multicolumn{2}{|c|}{ Cecha } & \multicolumn{2}{c|}{ Ocena spółdzielni } \\
\cline { 3 - 4 } & & grupa A & grupa B \\
\hline 1 & Wpływ głównych dostawców na ilość skupionego mleka & 4,0 & 3,6 \\
\hline 2 & Możliwość zmiany odbiorcy przez dostawców mleka & 1,9 & 4,0 \\
\hline 3 & Wpływ dostawcy na jakość uzyskiwanego mleka & 4,5 & 4,4 \\
\hline 4 & Wpływ zmiany dostawcy na koszty & 1,6 & 4,4 \\
\hline 5 & Wpływ dostawców na kierunki działań spółdzielni & 2,7 & 2,5 \\
\hline \multicolumn{2}{|r}{ Średnio } & 2,9 & 3,8 \\
\hline
\end{tabular}

Źródło: Badania własne.

Siłą kształtującą otoczenie spółdzielni jest siła przetargowa nabywców. Nabywcy mogą dysponować dużą siłą przetargową w przypadku, gdy podaż przewyższa popyt. Nabywcy konkurują wówczas z sektorem mleczarskim wymuszając obniżanie cen, targując się o wyższą jakość lub zwiększenie zakresu obsługi oraz przeciwstawiając sobie konkurentów. Sytuację konkurencyjną obydwu grup spółdzielni mleczarskich pod względem siły przetargowej nabywców można określić jako niekorzystną (tab. 5). Wpływ poszczególnych cech, wyznaczających siłę przetargową odbiorców wobec spółdzielni, jest bardzo zbliżony w obydwu grupach i oceniany jako dość wysoki. Niekorzystna sytuacja konkurencyjna spółdzielni mleczarskich wynika szczególnie z wpływu odbiorców na wielkość sprzedaży (ocena 4,5) i możliwości zmian przez nich przedsiębiorstw produkujących przetwory mleczarskie (ocena 3,9). Nabywcy konkurują ze spółdzielniami mleczarskimi, przerzucając także na nie koszty zakupów i dostaw, głównie w spółdzielniach z grupy A (ocena 3,9), oraz wymuszając obniżanie cen, co jest bardziej widoczne w spółdzielniach grupy B (ocena 3,9). Siła przetargowa nabywców rośnie w miarę wzrostu skali sprzeda$\dot{z} y$, a skrajnie duża jest w przypadku zagranicznych sieci handlowych, poprzez które rozprowadzają swe produkty spółdzielnie grupy A (ocena 3,9 ), podczas gdy jest znacznie niższa w spółdzielniach z grupy $\mathrm{B}$ (ocena 2,8 ). Biorąc pod uwage prognozy przewidujące szybki postęp koncentracji w handlu żywnością i wzrost znaczenia zagranicznych sieci handlowych, można przyjąć, że zagrożenie $\mathrm{z}$ tej strony będzie wzrastać [Pietrzak 2001]. Na zbliżonym poziomie natomiast zarządzający spółdzielniami oceniają dyktowanie warunków zakupu przez nabywców (ocena 3,6-3,7).

Spółdzielnie mleczarskie znajdują się pod naciskiem konkurencji ze strony innych przedsiębiorstw sektora mleczarskiego. Przewagi, którymi może dysponować spółdzielnia mleczarska w stosunku do konkurentów, to przede wszystkim: posiadanie bardziej efektywnych technologii, wyższa dyferencjacja produktów, uznana 


\section{Tabela 5}

Ocena siły przetargowej nabywców (skala ocen 1-5)

\begin{tabular}{|c|c|c|c|}
\hline \multirow[t]{2}{*}{ Lp. } & \multirow{2}{*}{ Cecha } & \multicolumn{2}{|c|}{ Ocena spółdzielni } \\
\hline & & grupa $A$ & grupa B \\
\hline 1 & Wpływ odbiorców na wielkość sprzedaży & 4,5 & 4,5 \\
\hline 2 & Dyktowanie warunków zakupu & 3,7 & 3,6 \\
\hline 3 & $\begin{array}{l}\text { Możliwość zmiany przez odbiorców firm produkujących } \\
\text { wyroby mleczarskie }\end{array}$ & 3,9 & 3,9 \\
\hline 4 & $\begin{array}{l}\text { Możliwość przerzucania przez odbiorców kosztów zakupu } \\
\text { i dostaw na producentów wyrobów mleczarskich }\end{array}$ & 3,9 & 3,4 \\
\hline 5 & $\begin{array}{l}\text { Wpływ największych nabywców na producentów wyro- } \\
\text { bów mleczarskich }\end{array}$ & 3,9 & 2,8 \\
\hline 6 & $\begin{array}{l}\text { Wplyw informacji posiadanych przez odbiorców na prze- } \\
\text { bieg negocjacji zakupu }\end{array}$ & 3,6 & 3,0 \\
\hline 7 & $\begin{array}{l}\text { Wpływ detalistów na decyzje ostatecznych konsumentów } \\
\text { przy dokonywaniu zakupu }\end{array}$ & 3,4 & 3,0 \\
\hline 8 & Zmuszanie spółdzielni do obniżania cen & 3,5 & 3,9 \\
\hline & Srednio & 3,8 & 3,5 \\
\hline
\end{tabular}

Źródło: Badania własne.

marka handlowa, duża trwałość powiązań z klientami, wysokie kwalifikacje pracowników, niskie koszty pracy ludzkiej oraz tanie surowce [Skawińska 1998]. Najbardziej istotną ich determinantą jest duża liczba podmiotów działających na tym rynku, co wynika $z$ dużego rozdrobnienia przetwórstwa (średni roczny przerób mleka przez jeden zakład w Polsce wynosi $20 \mathrm{mln} 1$, podczas gdy w UE przekracza $130 \mathrm{mln}$ 1) [Zalewski 2000]. Ponadto, spółdzielnie grupy A, jako zakłady duże o ugruntowanej pozycji na rynku krajowym, opanowały najbardziej dochodowe segmenty rynku, koncentrując działalność na takich grupach asortymentowych, jak napoje mleczne, desery i produkty UHT. Z kolei spółdzielnie mleczarskie województwa świętokrzyskiego obsługuja zazwyczaj najbliższe rynki lokalne, koncentrując się na produkcji przetworów mlecznych o niskim stopniu przetworzenia. Spółdzielnie grupy A mają wyraźną przewage nad spółdzielniami świętokrzyskimi, której głównymi źródłami są wysoka jakość produkcji, duże zróżnicowanie produktów i duża skala produkcji. Spółdzielnie świętokrzyskie oceniają zdecydowanie gorzej stan posiadanych przez siebie zasobów w kontekście osiągnięcia standardów UE. Najgorzej oceniane są zasoby urządzeń produkcyjnych, środków transportu służących do odbioru mleka i zasobów finansowych. Przewagę konkurencyjną spółdzielnie grupy A osiągają również dzięki posiadaniu systemów HACCP i ISO [Wasilewski, Kowalczyk 2003b]. W związku z powyższymi uwarunkowaniami spółdzielnie grupy A mają lepsze możliwości realizowania ofensywnych strategii rynko- 
wych. Spółdzielnie świętokrzyskie ze względu na braki zasobów wytwórczych mają trudności $z$ wyprodukowaniem nowoczesnych produktów o najwyższej jakości. Stosowane przez nie strategie mają charakter bardziej defensywny, usiłują one bowiem utrzymać się na rynku. Konkurują o możliwość zbytu swych produktów obniżając ceny, co destabilizuje i pogarsza sytuację całego sektora.

Ocena stopnia natężenia konkurencji w sektorze mleczarskim jest stosunkowo zbliżona w obydwu grupach spółdzielni (tab. 6). Nieco silniejsze natężenie konkurencji w sektorze wykazują spółdzielnie grupy A, ale generalnie stopień natężenia konkurencji jest wysoki. Najwyższy stopień konkurencji spółdzielnie odczuwają w zakresie napojów mlecznych, serów i mleka spożywczego. Stosunkowo najmniejszy stopień konkurencji w spółdzielniach z grupy A występuje w przypadku mleka w proszku oraz masła (ocena 3,9), natomiast najwyższy dotyczy serów oraz śmietany (oceny 4,3 ). Ze względu na uboższą ofertę przetworów mleczarskich spółdzielni świętokrzyskich najsilniejszą konkurencje spółdzielnie te upatrują $w$ takich produktach, jak mleko spożywcze i napoje mleczne, najniższą natomiast w zakresie mleka w proszku (ocena 2,8 ).

\section{Tabela 6}

Stopień natężenia konkurencji w zakresie produktów wytwarzanych przez spółdzielnie (skala ocen 1-5)

\begin{tabular}{|l|l|c|c|}
\hline \multirow{2}{*}{ Lp. } & \multirow{2}{*}{ Cecha } & \multicolumn{2}{|c|}{ Ocena spółdzielni } \\
\cline { 2 - 3 } & & grupa A & grupa B \\
\hline 1 & Mleko spożywcze & 4,1 & 4,3 \\
\hline 2 & Sery twarogowe & 4,3 & 3,8 \\
\hline 3 & Sery topione i dojrzewające & 4,3 & 3,8 \\
\hline 4 & Mleko w proszku & 3,9 & 2,8 \\
\hline 5 & Śmietana i śmietanka & 4,3 & 3,8 \\
\hline 6 & Masło & 3,9 & 3,7 \\
\hline 7 & Napoje mleczne Srednio & 4,2 & 4,0 \\
\hline & & 4,1 & 3,7 \\
\hline
\end{tabular}

Źródło: Badania własne.

Pojawienie się nowego przedsiębiorstwa na rynku powoduje zmianę jego charakteru i właściwości, przejawiających się m.in. w zmianach cen, konieczności redukcji kosztów lub zwiększeniu się ogólnej konkurencyjności. Dlatego też znajomość sytuacji w sektorze w zakresie możliwości pojawienia się innych podmiotów na rynku jest bardzo ważna. Bariery wejścia do sektora ograniczają możliwość swobodnego wniknięcia nowych przedsiębiorstw na dany rynek. Poziom barier wejścia do sektora mleczarskiego oceniany jest przez zarządza- 
jących spółdzielniami mleczarskimi jako umiarkowany, na poziomie bardzo podobnym w obydwu grupach spółdzielni (tab. 7). Za najpoważniejsze ograniczenie uważa się duże potrzeby kapitałowe związane z rozpoczęciem działalności (ocena 4,6). Oznacza to, że podmiot wchodzący do sektora mleczarskiego, chcąc dorównać przedsiębiorstwom już w nim działającym, będzie potrzebował znacznych środków kapitałowych, niezbędnych do uruchomienia procesu produkcji. Innym wysoko ocenianym czynnikiem stanowiącym barierę wejścia jest trudny dostęp do sieci dystrybucji (ocena 4,5). Ze względu na niższą skalę produkcji w spółdzielniach świętokrzyskich oceniają one znaczenie efektów skali produkcji jako bariere wejścia nowych firm jako dość duże zagrożenie dla swojej pozycji na rynku (ocena 3,6). Najniżej w obu grupach spółdzielni zostały ocenione cechy dotyczące działalności odwetowej przedsiębiorstw już działających na rynku mleka w stosunku do wchodzących oraz polityka państwa, związana $\mathrm{z}$ utrudnianiem wchodzenia nowych podmiotów na rynek mleczarski. Jednocześnie zagrożenie wejściem nowych jednostek na rynek dotyczy głównie produktów o wysokim stopniu przetworzenia i gwarantujących osiaganie wyższej opłacalności. W tym kontekście zagrożenie ze strony nowych konkurentów dotyczy w większym stopniu spółdzielni grupy A niż spółdzielni świętokrzyskich.

Firmy wytwarzające wyroby substytucyjne mogą stanowić istotne zagrożenie dla przedsiębiorstw danego sektora, szczególnie w przypadku pojawienia się nowych technologii produkcji substytutów. Wyroby substytucyjne ograniczają potencjalne zyski w danym sektorze, ustalając niższy pułap cen. Efektem

\section{Tabela 7}

Ocena barier wejścia nowych przedsiębiorstw do sektora mleczarskiego (skala ocen 1-5)

\begin{tabular}{|l|l|c|c|}
\hline Lp. & \multirow{2}{*}{ Cecha } & \multicolumn{2}{|c|}{ Ocena spółdzielni } \\
\cline { 3 - 4 } & & grupa A & grupa B \\
\hline 1 & Występowanie w sektorze tzw. efektu skali & 3,0 & 3,6 \\
\hline 2 & $\begin{array}{l}\text { Poziom zróżnicowania wyrobów pod względem pozycji } \\
\text { marki }\end{array}$ & 3,7 & 3,1 \\
\hline 3 & Trudności związane z dostępem do sieci dystrybucji & 4,5 & 4,5 \\
\hline 4 & Duże potrzeby kapitałowe & 4,6 & 4,6 \\
\hline 5 & Gorsza sytuacja kosztowa & 4,4 & 3,4 \\
\hline 6 & $\begin{array}{l}\text { Działalność odwetowa ze strony przedsiębiorstw } \\
\text { istniejących }\end{array}$ & 1,8 & 1,9 \\
\hline 7 & Polityka państwa wobec nowych podmiotów & 2,1 & 2,1 \\
\hline \multicolumn{2}{|c}{ Średnio } & 3,4 & 3,3 \\
\hline
\end{tabular}

Żródło: Badania własne. 
jest ograniczenie teoretycznie możliwej rentowności sektora. Ponadto, pojawienie się substytutu wiąże się ze spadkiem sprzedaży dotychczasowego produktu, a to może powodować nasilenie konkurencji wewnątrz sektora. Możliwość pojawienia się produktów substytucyjnych w sektorze mleczarskim oceniana jest przez zarządzających spółdzielniami jako niewielka. Wynika to głównie z właściwości mleka i jego przetworów jako produktów pochodzenia zwierzęcego. Jedynym produktem mleczarskim znacznie zagrożonym substytutami (thuszcze roślinne) jest masło. Innymi produktami substytucyjnymi dla mleka krowiego mogą być mleko kozie, owcze i sojowe. Wyroby te stanowią jednak niewielkie zagrożenie ze względu na bardzo małą skalę produkcji.

\section{Podsumowanie}

Celem badań była analiza porównawcza poziomu konkurencyjności spółdzielni mleczarskich eksportujących wyroby na rynki UE i spółdzielni z województwa świętokrzyskiego, takich uprawnień nie posiadających. Na podstawie przeprowadzonych badań sformulowano następujące wnioski.

1. Spółdzielnie eksportujące produkty mleczne na rynki UE odnotowały w latach 1998-2001 znaczacy wzrost przerobu mleka (o 25\%), podczas gdy w spółdzielniach województwa świętokrzyskiego nastapił spadek o 15,5\%. W spółdzielniach grupy B liczba dostawców była ponaddwukrotnie niższa niż w grupie spółdzielni A i zmniejszyła się o $26,8 \%$, co może ograniczyć ich możliwości rozwojowe. Spółdzielnie te charakteryzowały się także ponadtrzykrotnie większą wielkością średniej dostawy mleka, co daje korzyści efektu skali. Jednocześnie średni udział mleka klasy extra w tych spółdzielniach wynosił 76,2\% i zwiększył się aż o 30,1 pkt. Proc. podczas gdy $\mathrm{w}$ spółdzielniach grupy B udział ten wynosił jedynie 24,7\%. Spółdzielnie z grupy B w 2001 r. poniosły stratę na działalności, podczas gdy w grupie spółdzielni A wystapił znaczny wzrost zysku, wyższy niż tempo wzrostu przychodów. W analizowanym okresie nastapiło zatem pogorszenie sytuacji finansowej spółdzielni świętokrzyskich.

2. Siła przetargowa dostawców jest większa w grupie spółdzielni świętokrzyskich, zwłaszcza w zakresie wpływu zmiany dostawcy na koszty i możliwości zmiany odbiorcy przez dostawców mleka. Ze względu na niską koncentrację produkcji spółdzielnie świętokrzyskie nie są w stanie osiagnąć przewagi kosztowej. Pozycja konkurencyjna spółdzielni grupy A jest silniejsza, przy czym ich siła przetargowa jest niższa w przypadku wpływu głównych dostawców na ilość skupowanego mleka oraz na kierunki działań 
spółdzielni. Spółdzielnie świętokrzyskie powinny natomiast dążyć do umocnienia swej pozycji konkurencyjnej przez łączenie się $\mathrm{z}$ innymi podmiotami.

3. Największego zagrożenia obydwie grupy spółdzielni upatrują w sile oddziaływania nabywców na wielkość sprzedaży oraz możliwości zmiany przez odbiorców spółdzielni. W przypadku spółdzielni świętokrzyskich siła przetargowa nabywców jest niższa w zakresie wpływu posiadanych przez nich informacji na przebieg negocjacji zakupu oraz wpływu detalistów na decyzje ostatecznych konsumentów przy dokonywaniu zakupów. Spółdzielnie te są bardziej zmuszane do obniżania cen niż spółdzielnie z grupy A, które $\mathrm{z}$ kolei sq̨ bardziej podatne na dyktowanie przez odbiorców warunków zakupu, łącznie z kosztami zakupu i dostaw.

4. Stopień natężenia konkurencji w zakresie wytwarzanych produktów w obu grupach spółdzielni był zbliżony, najwyższy w przypadku mleka spożywczego, serów oraz śmietany, w najmniejszym natomiast stopniu dotyczył mleka w proszku i masła. Jako największe bariery wejścia nowych przedsiębiorstw do sektora mleczarskiego określono konieczność pokrycia dużych potrzeb kapitałowych oraz trudności związane z dostępem do sieci dystrybucji. W spółdzielniach eksportujących na rynki UE w większym zakresie jako barierę określono gorszą sytuację kosztową nowych przedsiębiorstw, a w spółdzielniach świętokrzyskich zwrócono w większym stopniu uwage na występowanie w działalności gospodarczej efektu skali działalności. Stosunkowo niewielką barierą wejścia nowych przedsiębiorstw do sektora mleczarskiego jest działalność konkurencyjna przedsiębiorstw już istniejących oraz polityka państwa wobec nowo powstających podmiotów gospodarczych. Możliwość pojawienia się produktów substytucyjnych w sektorze mleczarskim oceniana jest przez zarządzających spółdzielniami jako niewielka. Jedynym produktem mleczarskim, który jest znacznie zagrożony substytutami (tłuszcze roślinne) jest masło.

\section{Literatura}

Analizy Rynkowe, nr 22, 2002: Rynek mleka. Stan i perspektywy. MRiRW, ARR, IERiGŻ, Warszawa.

CHECHELSKI P., MORKIS G., 2002: Wydajność pracy w przemyśle spożywczym Polski i Unii Europejskiej. IERiGŻ, Warszawa.

JURCZAK M., 1997: Mleko - produkcja, badanie, przerób. Wydawnictwo SGGW, Warszawa.

PIETRZAK M., 2001: Analiza sytuacji konkurencyjnej przemysłu mleczarskiego przy zastosowaniu pięcioczynnikowej metody Portera (część 2). Przegląd Mleczarski nr 4, Warszawa. 
PORTER M.E., 1992: Strategia konkurencji. Metody analizy sektorów i konkurentów. PWE Warszawa.

SKAWIŃSKA E., 1998: Uwarunkowania rozwoju mleczarstwa polskiego w procesie integrowania Polski z Unią Europejska. Tom II - Konkurencyjność i perspektywy. TSZ.

SKAWENSKA E., 1999: Uwarunkowania rozwoju mleczarstwa polskiego w procesie integrowania Polski z Unią Europejska. Synteza. TNOiK, Toruń.

SKAWIŃSKA E., 2000: Siła konkurencyjna przedsiębiorstw na rynku. Przegląd Mleczarski nr 4, Warszawa.

WASILEWSKI M., KOWALCZYK A., 2003a: Kondycja finansowa spółdzielni mleczarskich w Polsce. Zeszyty Naukowe SGGW, Ekonomika i Organizacja Gospodarki Żywnościowej nr 50, Wydawnictwo SGGW, Warszawa.

WASILEWSKI M., KOWALCZYK A., 2003b: Jakościowe uwarunkowania działalności spółdzielni mleczarskich. [w:] Funkcje obszarów wiejskich w dobie transformacji gospodarki Polski. Wydawnictwo Akademii Świętokrzyskiej, Kielce.

\section{The evaluation of Dairy Cooperatives' Competitiveness}

\section{Abstract}

The study presents the comparative analysis of competitiveness' level of dairy cooperatives, which exports their products to the UE market and cooperatives from Świettokrzyskie province, which are not entitled to the export to the UE market. Cooperatives exporting their products to the UE market (group A) in the years 1998-2001 showed the increase of milk processing while in cooperatives from Świętokrzyskie province the decrease ensued. The cooperatives from group A were also characterized by three times higher level of average delivery of milk as well as the share in the purchase of extra class milk. In 2001 cooperatives Świętokrzyskie province incurred loss while group A cooperatives achieved increasing significant profit. The competitive strength of milk deliverers is larger in a group of cooperatives in Swiętokrzyskie province because those cooperatives do not achieve the cost advantage for the sake of the low concentration of the production. The biggest threat to dairy cooperatives is in the buyers' strong influence on the volume of sale and in buyers' possibility to change a cooperative delivering them dairy products. The level of competition's intensity in the scope of products offered by cooperatives was similar, highest in the case of milk, cheese, sour and sour cream and lowest in case of powder milk and butter. The necessity of covering large capital needs as well as difficulties in access to distribution channels were described as largest barriers to entry and considerable small barrier is the competitive activity of already existing enterprises. In the opinion of cooperatives' managers the possibility of appearing new substitutes of dairy products, except for butter, is low. 